
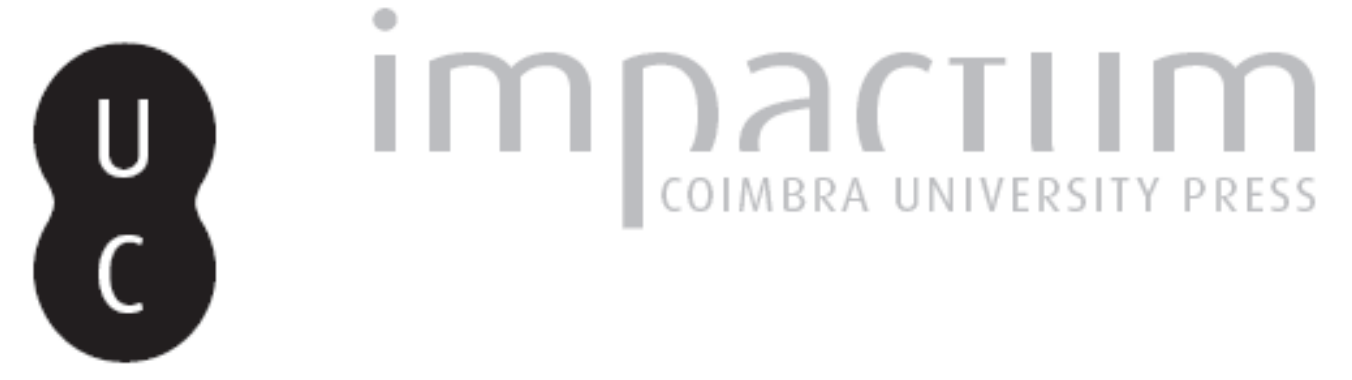

\title{
Pluralismo Jurídico e Estado Local em Angola: um olhar crítico a partir do estudo de caso do Bailundo
}

\author{
Autor(es): $\quad$ Florêncio, Fernando
}

Publicado por: CIAS - Centro de Investigação em Antropologia e Saúde

URL persistente:

URI:http://hdl.handle.net/10316.2/28576

DOI:

DOI:http://dx.doi.org/10.14195/2182-7982_28_4

Accessed : $\quad$ 26-Apr-2023 16:07:34

A navegação consulta e descarregamento dos títulos inseridos nas Bibliotecas Digitais UC Digitalis, UC Pombalina e UC Impactum, pressupõem a aceitação plena e sem reservas dos Termos e Condições de Uso destas Bibliotecas Digitais, disponíveis em https://digitalis.uc.pt/pt-pt/termos.

Conforme exposto nos referidos Termos e Condições de Uso, o descarregamento de títulos de acesso restrito requer uma licença válida de autorização devendo o utilizador aceder ao(s) documento(s) a partir de um endereço de IP da instituição detentora da supramencionada licença.

Ao utilizador é apenas permitido o descarregamento para uso pessoal, pelo que o emprego do(s) título(s) descarregado(s) para outro fim, designadamente comercial, carece de autorização do respetivo autor ou editor da obra.

Na medida em que todas as obras da UC Digitalis se encontram protegidas pelo Código do Direito de Autor e Direitos Conexos e demais legislação aplicável, toda a cópia, parcial ou total, deste documento, nos casos em que é legalmente admitida, deverá conter ou fazer-se acompanhar por este aviso.

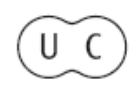




\section{Antropologia Portuguesa}

Departamento de Antropologia | Universidade de Coimbra

Volume $28 \cdot 2011$ 


\title{
Pluralismo Jurídico e Estado Local em Angola: um olhar crítico a partir do estudo de caso do Bailundo
}

\author{
Fernando Florêncio \\ CRIA \\ Departamento de Ciências da Vida \\ Universidade de Coimbra, Portugal \\ fjpf@ci.uc.pt
}

Resumo Com o fim dos regimes de Estado-Partido e de monopartidarismo centralista, dos finais da década de 1980, e com as transições para o multipartidarismo, os estados africanos, passaram, a partir de meados da década de 1990, a incorporar formas de organização social derivadas de sectores sociais até então "marginalizados", tradicionais ou não, tentando sempre no entanto enquadrá-las e controlá-las no processo de construção do estado, sobretudo ao nível local de base, ou seja, no chamado Estado Local. É neste novo contexto que o pluralismo social voltou a ganhar espaço e contexto. À semelhança dos estados coloniais, os estados independentes passaram a reconhecer a existência, no espaço nacional, de diversas ordenações jurídicas, no que se pode denominar de neo-indirect rule.

Este artigo pretende discutir criticamente as vantagens e os limites do pluralismo jurídico em África, em contextos políticos de weak states, a partir do caso de estudo do Município do Bailundo, na Província do Huambo em Angola.

Palavras-chave Pluralismo jurídico; autoridades tradicionais; estado local; Angola; Bailundo.

Abstract With the end of the centralized Party-State African political regimes, in late 1980's, and with the transitions for democracy and political pluralism, the African states decided to incorporate, in the 1990's, different types of social organizations, traditional or others, in the process of State building, namely in the so called Local State. In this new political context, the African State recognized the existence of different Legal Orders within the national boundaries, and Legal Pluralism reappeared, much as in the same manner as for colonial State, in a process that we might call it neo-indirect rule.

This article aims to discuss critically the scope and limits of Legal Pluralism in Africa, in the context of weak states political regimes, with the case study of the Município of Bailundo, in the central Province of Huambo in Angola.

Key words Legal pluralism; traditional authorities; local state; Angola; Bailundo. 


\section{Introdução}

Os estados africanos independentes apresentam uma enorme heterogeneidade nos seus processos de construção e de consolidação, resultantes de diversos factores, endógenos e exógenos. Podemos assinalar, entre outros, as formas de organização social local pré-coloniais, e suas articulações; as lógicas coloniais, quer comparativamente entre as diferentes potências, quer no seio de cada uma entre os diferentes territórios e períodos históricos; as formas de ascensão à independência; e, finalmente, os modelos de sistemas políticos e administrativos e as alianças estratégicas internacionais adoptadas pelos estados independentes. Claro que todos estes factores concorreram para uma história política plural ao nível da África subsaariana.

Contudo, e apesar desta pluralidade de modelos de desenvolvimento, de sistemas administrativos e políticos, implementados desde as independências, alguns fenómenos sociais foram-se estabelecendo em comum entre os diversos estados independentes. De entre estes fenómenos, podemos destacar: uma tendência geral para consolidar sistemas político-administrativos fortemente estatizados e centralizados, em torno de regimes políticos de partido-único; uma forte partidarização da sociedade e concomitante asfixia da sociedade civil; uma crescente crise dos modelos de desenvolvimento; uma crescente fixação em estratégias patrimonialistas de apropriação dos recursos e das trocas internacionais, por parte das elites dirigentes; e, finalmente, uma crescente retracção social e perda de legitimidade dos estados e dos partidos-estado.

Este panorama comum, caracterizado de forma excelente por autores como Jean-François Bayart (Bayart, 1989), a partir de meados da década de 1980 sofreu alterações significativas, caracterizadas, primeiro por uma necessidade generalizada de implementação de acordos com o Banco Mundial e com o FMI, e por conseguinte de adopção de políticas de desenvolvimento liberais; e, num segundo modelo, por uma necessidade, interna e externa, de alterar os sistemas políticos vigentes e adoptar modelos políticos liberais, democráticos e multipartidários, processo esse que ficou amplamente conhecido como "transições para a democracia".

É precisamente neste novo contexto político que, a partir ainda dos finais da década de 1980, mas substancialmente já na década de 1990, começam a desenhar-se progressivamente em toda a África subsaariana novos modelos de reconfiguração político-administrativa dos estados. As "aberturas" con- 
figuraram o surgimento de novos actores sociais nas arenas políticas, como partidos políticos, organizações cívicas, associações diversas, sindicatos independentes, etc., ou consolidaram "velhos" actores, tais como as igrejas e as autoridades tradicionais.

Por outro lado, e num outro sentido, estes processos de reconstrução do estado africano trouxeram novas configurações do poder político e do estado, apostando em modelos de desconcentração do poder e de descentralização administrativa, envolvendo estes novos e "velhos" actores. De certo modo pode dizer-se que, muito pragmaticamente, os estados e os respectivos poderes centrais entenderam que a "sobrevivência" passava por englobarem a sociedade, reconhecendo a existência de outros actores, com diferentes legitimidades sociais, e inseridos noutras formas, locais ou nacionais, de organização social.

É neste novo fórum que o pluralismo social voltou a ganhar espaço e contexto. À semelhança dos estados coloniais, os actuais estados independentes perceberam a vacuidade dos processos de centralização políticoadministrativa, e de hegemonia do estado e aniquilamento de outras formas de organização social, política, jurídica e religiosa, nomeadamente as de carácter etno-linguísticas. Neste contexto, os estados passaram, a partir de meados da década de 1990 a "aceitar" a existência das formas de organização social tradicionais, tentando sempre no entanto enquadrá-las e controlá-las no processo de construção do estado, sobretudo ao nível local base, em especial nos espaços rurais.

O pluralismo jurídico é parte integrante desse pluralismo social, e o reconhecimento da existência de outras ordens jurídicas dentro dos espaços nacionais. Como sublinha John Griffiths, citado por Tiago Fernandes, o pluralismo jurídico refere-se à "presença de mais do que uma ordem normativa num campo social (Fernandes, 2009: 40). Por seu turno Boaventura Sousa Santos, igualmente citado por Tiago Fernandes esclarece que existe um pluralismo jurídico interno, que se reporta "à diversidade de práticas administrativas que se opera dentro das próprias instituições" (Fernandes, 2009: 41), e o pluralismo externo, que se prendem com ordens normativas externas ao estado e "formas de legitimação política não oficial ou mesmo tradicional" (Fernandes, 2009: 43). Como reforça Tiago Fernandes, é a esta segunda forma que normalmente se apelida de pluralismo jurídico. Nesse âmbito, o pluralismo jurídico define então a co-existência de diferentes formas de ordenação normativa e de regulação de conflitos, estatais e não- 
estatais, entre as quais se pode sublinhar os regimes jurídico-normativos das sociedades tradicionais e que são dirigidos pelas autoridades tradicionais.

Em certa medida, a grande maioria dos estados pode ser caracterizada como de weak states, segundo a classificação de John Migdal (Migdal, 1988), com fraca penetração territorial e fraca legitimidade e controlo, sobre a totalidade das populações e do território. Neste sentido, pode dizer-se que os actuais processos de desconcentração e de descentralização visam precisamente o reforço do estado, e sobretudo do estado central e dos partidos dominantes. Expandido o seu controlo e a sua legitimidade, e alargando a rede de estruturas administrativas à totalidade do território. Ora, no pressuposto da construção soberana e unitária dos estados, e face às características de weak states, a co-habitação de diferentes ordens e regulações jurídicas pode causar problemas, quer à unidade do estado, quer até mesmo à sua legitimação.

Tiago Fernandes, que sublinha este aspecto a propósito do caso moçambicano, questiona como é que,

"o Estado moçambicano consegue cumprir a missão de consolidação da sua soberania em todo o território nacional, num contexto em que:

a) Existem vários actores políticos locais que não são oficialmente reconhecidos pelo Estado, mas legitimados pelas populações (...);

b) Existem vários actores políticos locais oficialmente reconhecidos pelo Estado, mas que, por discordância política ou incapacidade técnica, desobedecem frequentemente à lei do Estado, exercendo ainda assim soberania sobre uma parcela do território nacional e sobre as populações locais; e

c) Existe uma pluralidade de sistemas jurídicos originários (o sistema assente no direito positivo e os vários sistemas assentes em fontes de Direito consuetudinário).” (Fernandes, 2009: 51).

Em boa verdade, o que se pode constatar é que nas actuais condições o pluralismo jurídico, em face das "fraquezas" do estado central, pode colocar em confrontação, ao nível local, o direito estatal com o direito consuetudinário. É nesse sentido que as autoridades tradicionais têm jogado um relevante papel, por um lado de intermediários do estado, ao nível local, mas por outro de concorrentes em termos da sua condição de reguladores das ordens jurídicas locais. Como salienta Trutz von Thotha, 
"Chieftaincy has not only gained influence from the need of a weak state for the administrative help of the chief to reach the population (...). Chieftaincy has also established itself as a neo-traditional institution which dominates in many ways the local order and fulfils many functions. The most important function of chieftaincy is probably the legal one. (...) Contrary to the law in the books, the chief is the 'veritable judge' and the chiefly legal courts is the basic institution of legal dispute resolution in the colonial and postcolonial African state. The chief's legal function is situated at the intersection of the administrative tasks of the chief as part of a unified central administration and the singularity of the local order. In the 'shadow of the state' the chief guarantees the orderly resolution of normative conflicts and at the same time upholds the traditional local legal system. (...) The chief and the member of his court are leading figures in the local hierarchy of social relations and are at the center of the local order of meaning. They represent the local traditions and have to handle them according to present needs, interests and values" (Trotha, 1996: 85).

Desta proposta de Trutz von Trotha podem inferir-se dois dos assuntos mais problemáticos da integração das autoridades tradicionais nos processos de formação do estado em África: o lugar ambivalente das autoridades tradicionais e a integração de ordens jurídicas controversas. Problema que os estados coloniais, mesmo com a criação do sistema de indirect rule, sempre se confrontaram, e que os estados independentes acabam por herdar e perpetuar. No primeiro caso, o sistema de indirect rule, que durante muito tempo era encarado como uma relação de dominação-subordinação dos estados coloniais sobre as autoridades tradicionais ${ }^{1}$, começa agora a ser encarado como uma relação muito mais complexa e ambivalente, em que ambos os actores usam as suas capacidades e legitimidades, ora reforçandose mútua e estrategicamente, quer em termos de legitimidade quer de fontes de dominação, ora degladiando-se, pela dominação da relação (Florêncio, 2003; 2005; 2008; 2009).

${ }^{1}$ Um dos expoentes desta leitura é sem dúvida Trutz von Trotha que no artigo de 1996, "From Administrative to Civil Chieftaincy. Some Problems and Prospects of African Chieftaincy", argumenta precisamente que os estados coloniais esvaziaram as autoridades tradicionais ao ponto de as encapsularem em tarefas meramente administrativas. Uma possível crítica a esta postura pode-se encontrar em Florêncio (2005; 2008) 
Aliás, este ponto é bem elucidado por Marques Guedes, ao escrever que o "Indirect rule does increase State capabilities, also at the level of local recognition (...). Likewise, mechanisms of indirect rule do indeed also offer local chiefs a supplement both of force and legitimacy (...)", e ainda para consubstanciar a complexidade da relação, "Both State and local social actors have what are often fairly clear-cut agendas (...)" (Guedes, 2007: 57).

Num segundo ponto, os estados têm desenvolvido estratégias no sentido de exercerem um controlo quer sobre as autoridades tradicionais quer sobre as suas capacidades e limites jurídicos, nomeadamente tentando determinar e impor uma hierarquia de competências jurídicas entre os diferentes actores e as diferentes ordenações legais locais e o direito estatal nacional.

Nesse sentido, N'Gunu Tiny defende que existem dois modelos de acomodação ${ }^{2}$ das autoridades tradicionais e dois sistemas costumeiros no sistema legal nacional: o monista, ou de integração; e o dualista, ou de reconhecimento. No primeiro caso, as autoridades tradicionais são integradas como parte da administração pública, numa espécie de sistema de indirect rule ${ }^{3}$, sendo que essa integração no aparelho administrativo local pode nem ser formal. No segundo modelo, as autoridades tradicionais são encaradas enquanto representantes e líderes das suas próprias comunidades, por conseguinte como uma instituição autónoma do estado local (Tiny, 2007: 74). Tiago Fernandes sublinha, a este propósito, que as fontes de legitimação das autoridades tradicionais variam assim consoante o tipo de modelo adoptado, no modelo monista, a sua legitimidade deriva da sua pertença ao aparelho administrativo estatal, enquanto no modelo dualista deriva directamente das populações subordinadas (Fernandes, 2009: 52, 53).

Contudo, segundo N'Gunu Tidy, em qualquer dos modelos a relação entre o Estado e as autoridades tradicionais é sempre encarada de um prisma hierárquico de subordinação dos segundos aos primeiros, isto é, nenhum dos dois modelos expressa uma verdadeira visão pluralista da relação (Tiny, 2007: 74). Neste sentido os sistemas legais costumeiros devem subordinar-se e conformar-se sempre com o Direito estatal e com as normas constitucionais nacionais.

\footnotetext{
${ }^{2}$ No original em inglês usa-se o termo "accommodation".

${ }^{3}$ Sobre a pertinência da utilização actual do termo indirect rule ou sua substituição pela expressão neo indirect rule cf. Florêncio (2008).
} 
Neste artigo, que se centra em dados empíricos recolhidos em 2004 e 2007 no município do Bailundo, na província do Huambo ${ }^{4}$, pretende-se assim equacionar através das práticas e das representações dos actores locais, nomeadamente das autoridades do reino do $\mathrm{M}^{\prime} B$ Balundu e dos agentes do estado municipal, a mise en scéne desta diferenciação entre modelo monista e dualista, e, no fundo avaliar em que medida as duas ordens jurídicas locais, a tradicional e a estatal, se complementam ou se, pelo contrário, se contradizem. Enquanto problema teórico mais amplo, pretende-se deste modo discutir quais as vantagens e desvantagens, ou perigos, que o pluralismo jurídico afronta num weak state como Angola, ainda em processo de reconstrução e de consolidação nacional.

\section{O estado colonial e o pluralismo jurídico}

Muitos teóricos e defensores do colonialismo português sempre defenderam a tese da vocação civilizacional, enquanto princípio basilar ${ }^{5}$ do próprio projecto colonial, e de que os indígenas e suas "culturas" deveriam ser progressiva e selectivamente assimilados na civilização portuguesa. Esta política assimilacionista defendia que, no entanto, enquanto tal não sucedesse cabalmente os indígenas deveriam ser mantidos e respeitados nas suas tradições e costumes. Neste sentido, desde finais do século XIX, a produção legislativa colonial, nos seus vários domínios, vai acentuando progressivamente a existência de dois tipos de sociedades dentro do mesmo espaço colonial, a sociedade colonizadora (branca, europeia, conforme as designações), e as sociedades indígenas (gentias, nativas) ${ }^{6}$.

Essa distinção aprofundou-se, legislativamente na década de 1930, com a publicação de três documentos fundamentais do colonialismo português, com especial incidência para o Estatuto Político, Civil e Criminal dos Indí-

\footnotetext{
${ }^{4}$ Neste sentido, o presente artigo é subsidiário da investigação do autor no projecto "Dinâmicas Sociais na Estruturação dos Espaços Políticos em Contextos Rurais Africanos", pelo Centro de Estudos Africanos do ISCTE, financiado pela FCT, POCI/AFR/59228/2004.

${ }^{5}$ Obviamente não se discute neste texto a vacuidade desta argumentação, nem o carácter contraditório entre as teorizações colonialistas e as suas práticas locais.

${ }^{6}$ São inúmeros os projectos e códigos legislativos sobre o direito penal indígena, nesse sentido podemos, apenas a título de exemplo salientar o Projecto de Regulamento de Justiça Penal Indígena, de António Cabral, de 1925; o Projecto de Código de Milandos, do mesmo autor e do mesmo ano.
} 
genas da Guiné, Angola e Moçambique, publicado em 1929; a Constituição da República, de 1933; o Acto Colonial, de 193377; a Carta Orgânica e a Lei da Reforma Administrativa Ultramarina, ambas publicadas também em 1933. Por exemplo, no Acto Colonial (Decreto 18: 570), no título II sobre os indígenas, defende-se a existência de regulamentações e de direitos especiais para os indígenas não assimilados e a observância dos seus usos e costumes (Coimbra, 2008: 18).

No entanto, é o Estatuto Político, Civil e Criminal dos Indígenas da Guiné, Angola e Moçambique que apresenta, desde logo, alguns pontos importantes para a compreensão de todo o enquadramento político-administrativo a que ficaram sujeitas as sociedades africanas e as suas instituições de poder político. Este documento, como se disse, consubstancia e aprofunda o princípio da separação entre "indígenas" e "não indígenas". Este processo acarreta uma dupla subordinação, política e jurídica, das populações ou das sociedades "indígenas", facto bem elucidado nas palavras de Adriano Moreira:

"No fenómeno colonial verifica-se precisamente a circunstância de as sociedades indigenas terem perdido a sua independência e ficarem politicamente subordinadas a um Estado de que passam a fazer parte integrante" (Moreira, 1955: 70).

Segundo Adriano Moreira é precisamente na administração da justiça aos "indígenas" que se efectiva essa subordinação, pois como adianta este autor:

"Estabelecida esta situação de facto [a dominação colonial] é desde logo aparente que o sentido do Estado colonizador será o de chamar a si a administração da justiça, porque se trata do critério mais evidente da soberania e do mais importante dos fins do Estado" (Moreira, 1955: 70).

A perda de direitos para os "indígenas" fica bem patente no Artigo 7. do Estatuto Político, Civil e Criminal dos Indígenas, que adianta "não serão concedidos aos indigenas direitos políticos em relação a instituições de

${ }^{7}$ Apesar de publicado pela primeira vez em 1930, o Acto Colonial foi posteriormente revisto, devido à nova Constituição de 1933, e declarado matéria constitucional nesse mesmo ano de 1933. 
carácter europeu" ". A subordinação jurídica dos "indígenas" consuma-se com a criação dos Tribunais Privativos dos Indígenas. Estes tribunais regulavam as relações jurídicas entre "indígenas" e são independentes da organização judiciária portuguesa (Artigo $14{ }^{\circ}$ ), têm sede em cada circunscrição e são presididos pelo administrador que é coadjuvado por dois vogais, por si nomeados, e por dois assessores para "assuntos costumeiros", que podem ser dois chefes "ou outros indigenas de reconhecido prestígio e conhecimento das tradições jurídicas locais" (Artigo 15. ${ }^{\circ}, \S 2 .^{\circ}$ ).

A colonização portuguesa adopta assim o sistema de indirect rule, no qual as sociedades africanas ficam encarceradas, do ponto de vista político e jurídico, no que se entendia como o seu modelo tradicional de vida, ou seja segundo os seus usos e costumes. Certamente que o encarceramento de que se fala era mascarado, pelo menos no texto do Estatuto, pelo respeito dos modelos costumeiros, pois aí se diz que "um tal sistema, justo, prático e eficaz, envolve o respeito dêsses mesmos usos e costumes, em tudo o que não colida com (...) os princípios da humanidade e com a soberania de Portugal" 10 .

Neste modelo é claramente assumida a duplicidade política e jurídica da sociedade colonial, sendo vedada a uma parte significativa dessa mesma sociedade, às populações "indígenas", a integração plena na sociedade colonial, devendo assim continuarem a reproduzir-se segundo os seus modelos tradicionais de organização social. É neste sentido que assumem especial relevo as instituições políticas tradicionais, nomeadamente as autoridades tradicionais. Elas são, por um lado, a garantia da continuidade desse modelo de organização e, por outro lado, constituem a "ponte" institucional entre esses dois universos, colonizados e colonizadores, bem assim como a subordinação dos colonizados ao Estado português.

O Estatuto, vulgarmente designado como o Estatuto do Indigenato, sofreria algumas mudanças e aperfeiçoamentos, e em 1954 é publicado um novo Estatuto dos Indígenas Portugueses das Províncias da Guiné, Angola e

${ }^{8}$ In Estatuto Político, Civil e Criminal dos Indígenas da Guiné, Angola e Moçambique, 1939 [1929]: 10.

${ }^{9}$ Este processo de institucionalização do sistema de indirect rule consagra-se com a introdução da Reforma Administrativa Ultramarina, em 1933, que institucionaliza as autoridades tradicionais enquanto parte integrante do aparelho administrativo colonial.

${ }^{10}$ In Estatuto Político, Civil e Criminal dos Indígenas da Guiné, Angola e Moçambique, 1939: 4 . 
Moçambique (Decreto Lei, 39.666), que no essencial mantém as características anteriores, reforçando apenas a ideia de uma progressiva harmonização dos direitos costumeiros ao direito português, com vista à integração dos indígenas na civilização portuguesa. Finalmente, em 1961, com o Decreto Lei 48.893, revogou-se o Estatuto de 1954, terminando com a classificação de indígena e a distinção com os não indígenas.

No que respeita às autoridades tradicionais, este duplo papel de que se falava anteriormente, foi formalmente institucionalizado em 1933, com estabelecimento da Reforma Administrativa Ultramarina, Decreto Lei 23:229, de 15 de Novembro, que, entre outros assuntos, define a integração das autoridades tradicionais no aparelho administrativo colonial. A RAU, como ficou conhecida, define a divisão administrativa das colónias portuguesas e as funções de cada categoria de funcionários administrativos, e assume igualmente uma importância fulcral uma vez que define e institucionaliza o modelo de relacionamento entre o Estado colonial e as autoridades tradicionais.

No capítulo dos deveres e das funções das autoridades tradicionais ${ }^{11}$, destacam-se os seguintes pontos: 1) a obrigação de obedecer fielmente às autoridades administrativas portuguesas (Artigo 99..$^{\circ}$ § 1..$^{\circ}$ ); 2) publicitar as ordens da Administração (Artigo 99. ${ }^{\circ}, \S 2 .^{\circ}$ ); 3 ) manter a ordem na sua regedoria (Artigo 99..$^{\circ}$ § 3..$^{\circ}$ ); 4) fornecer homens para a polícia e o exército, sempre que solicitado (Artigo 99. $.^{\circ}, \S 4 .^{\circ}$ ); 5) participar à Administração sobre qualquer ocorrência extraordinária na regedoria, como crimes, falecimentos, doenças endémicas, comércio ilegal e demarcações de terrenos (Artigo 99. ${ }^{\circ}$, $\S 5 .^{\circ}$ ); 6) participar e registar casamentos, nascimentos e óbitos (Artigo 99. ${ }^{\circ}$, $\left.\S 6 .^{\circ}\right) ; 7$ ) impedir o comércio e fabrico de bebidas alcoólicas, e venenos (Artigo 99. $.^{\circ}, \S 7 .^{\circ}$ ); 8) impedir a prática de feitiçaria e adivinhações (Artigo $\left.99 .^{\circ}, \S 9 .^{\circ}\right)$; 9) prender criminosos ou suspeitos e entregá-los às autoridades administrativas, (Artigo 99. $.^{\circ} \S 14 .^{\circ}$ ); 9) incitar as populações a praticarem o tipo de agricultura que a Administração aconselhar (Artigo 99. ${ }^{\circ}, \S 16^{\circ}$ ).

No que respeita às suas atribuições de manutenção da ordem, é proibido às autoridades tradicionais a competência de julgarem qualquer tipo de crimes, mas apenas as de prender os suspeitos e relatar os factos à administração (Artigo 99. ${ }^{\circ}, \S$ único). As autoridades tradicionais podiam também pedir à

${ }^{11}$ Designadas na RAU por autoridades gentílicas. No caso de Angola estas autoridades denominavam-se de sobas, e em Moçambique e na Guiné, de régulos. 
Administração a expulsão dos seus territórios dos indivíduos perturbadores da ordem pública (Art. 100..$^{\circ}$ ).

Importa neste ponto realçar que, o modelo do indirect rule, ou de governação indirecta, descrito sobretudo na literatura colonial britânica, como tendo na sua génese o respeito pelas tradições e costumes das sociedades tradicionais africanas, na verdade nunca foi aplicado na íntegra em nenhuma colónia africana, dado que as administrações coloniais, incluindo a britânica, sempre o usaram de modo mais ou menos coercivo e manipulador (cf. Lombard, 1967). Nesse sentido, o termo serve essencialmente para descrever sobretudo uma forma de governação na qual a potência colonial usa os sistemas políticos tradicionais africanos como alicerces mais baixos do sistema administrativo. Deste modo, face à ausência de recursos significativos, humanos e económicos, e face à falta de legitimidade das administrações coloniais juntos das populações africanas, o sistema de indirect rule permitiu aos estados coloniais controlar os territórios e as populações africanas através do recurso, controlo e manipulação das suas autoridades políticas africanas.

No caso português, a incapacidade do Estado em controlar os territórios e as populações africanas, sobretudo no período anterior à $2^{\mathrm{a}}$ Grande Guerra Mundial, é bem conhecida ${ }^{12}$, e no presente caso de Angola importa sublinhar o exemplo adiantado por Fola Soremekun que, citando um relatório da American Board, de 1911, atesta que o governo colonial não tem capacidade de governação e que no "mato" são os pequenos comerciantes quem governa verdadeiramente (Soremekun, 1965: 171). É precisamente neste quadro que as instituições políticas tradicionais africanas assumem um papel de relevo. Elas constituem, paradoxalmente, a salvaguarda da continuidade do modelo de organização "indígena" e do modelo de administração colonial, e a intermediação institucional entre esses dois universos, entre colonizados e colonizadores.

No que diz respeito às atribuições jurídicas, e sobretudo no caso dos julgamentos, as autoridades tradicionais não só jogavam um importante papel, como eram fundamentais ${ }^{13}$. Em Angola, como em Moçambique, estes tribunais existiam em todos os escalões da estrutura das autoridades tradi-

${ }^{12}$ Sobre este assunto, e reportando-se ao caso moçambicano cf. Florêncio, 2003; $2005 ; 2008$.

${ }^{13}$ Sobre a importância do papel jurídico das autoridades tradicionais para a Administração colonial portuguesa, e sobre a sua concepção de uma espécie de pluralismo jurídico, bem patente na imposição do Estatuto do Indígena, cf Florêncio (2003: 241-243). 
cionais. No caso do Bailundo ${ }^{14}$, todas as autoridades tradicionais, nomeadamente os olossekulu ${ }^{15}$, os olossoma ${ }^{16}$ e o osssoma inene ${ }^{17}$, possuíam os seus tribunais tradicionais, que funcionavam em sistema hierárquico, um pouco à semelhança do que sucedida no período pré-colonial. Como argumenta 0 ossoma Jino Kaiangula da ombala $^{18}$ de Chijamba,

"os sékulus nas aldeias também tinham tribunais, mas quando não conseguiam solucionar o caso então era encaminhado ao soba. O soba tendo conclusão tudo bem, se não o caso era transferido à Administração. (...) Não ia ao rei. No tempo colonial ficava mesmo no soba. O rei também tinha o seu tribunal. (...) Podia resolver casos de ferimentos, violações, insultos, adultérios. Conflitos de terras também." (in EBai2004-04).

Estes tribunais circunscreviam-se apenas a contendas ou disputas entre indígenas, pois quer os assimilados quer os europeus não estavam abrangidos pelo Estatuto do Indigenato e regulavam os seus direitos e deveres pelo código civil. A grande maioria dos casos julgados nos tribunais das autoridades tradicionais envolviam ou relações de adultério ou, sobretudo, casos de feitiçaria, pois como adianta o ossoma de Chijamba, "os casos eram mais de feiticismo e adultério" (in EBai2004-4). O mesmo sublinha o ossoma Adolfo Chitoma da ombala de Lunge, ao dizer que "Tinha que haver justiça aqui na ombala. Isso nunca acabou, feitiçarias, roubalheiras, esses de caçar as mulheres dos outros, porradas, tudo isso. Desde os tempos passados" (in EBai2004-06).

\section{O pluralismo jurídico em Angola}

Para compreender os actuais processos de incorporação das autoridades tradicionais angolanas no processo de formação do Estado, nomeadamente

\footnotetext{
${ }^{14}$ Para a compreensão da estrutura de poder tradicional do reino do M'Balundu e da sua integração pelo Estado colonial cf. Florêncio (2009).

${ }^{15}$ Olossekulu é o plural de sekulu, que é o termo Umbundo para chefe de aldeia.

${ }^{16}$ Olossoma é o plural de ossoma, ou seja de chefe, a quem os portugueses designavam por soba.

${ }^{17}$ Ossoma inene significa literalmente chefe grande, e em geral serve para designar o rei, que também pode ser designado por ossoma olossoma, ou seja chefe dos chefes.

${ }^{18}$ Ombala é o local onde vive o ossoma e a sua corte. Pode considerar-se como uma espécie de capital do seu território, e ao mesmo tempo o centro político, jurídico e mágico religioso.
} 
a partir do final da guerra civil em 2002, a obra de Marques Guedes e Maria José Lopes torna-se um marco incontornável (Guedes e Lopes, 2007). De acordo com Marques Guedes, o Estado angolano já sentia a necessidade de incorporar as autoridades tradicionais no processo de controlo do território e das populações, desde o final da década de 1980, e a partir de 1992 atribuiu fardamentos, em tudo semelhantes ao que o Estado colonial tinha atribuído às autoridades tradicionais, um subsídio mensal, e, em certos casos, até mesmo veículos ou motorizadas (Guedes, 2007: 31). Marques Guedes, retomando algumas das propostas teóricas já avançadas pela literatura, fala do papel de intermediários das autoridades tradicionais ${ }^{19}$, ou como estando "half-way points between the 'local' and the 'central" (Guedes, 2007: 31).

$\mathrm{Na}$ obra citada, e a partir de quatro exemplos recolhidos na província do Huambo, o autor analisa algumas dimensões das relações entre as autoridades tradicionais angolanas e o Estado. No primeiro caso, ocorrido em Novembro de 2002, na comuna de Sambo, um homem, acusado de prática de feitiçaria, foi seviciado pela população local, facto que não resultou em homicídio devido à intervenção do ossoma local. O caso foi depois apresentado ao administrador da comuna, sob a acusação de feitiçaria. O administrador decidiu não dar provimento ao assunto. A população e o ossoma decidiram levar o acusado ao ossoma inene do Sambo, Cipriano Kaningi. Este finalmente decidiu "exilar" o acusado para uma comuna distante, em Chipeio, no município de Ecunha. Analisando o caso numa perspectiva legal, Marques Guedes avança com a ideia de que o administrador mostrou uma ambivalência sobre o caso, não o recusando nem o resolvendo, e que o ossoma inene mostrou igualmente estar "on the path to internalizing legal hybridism (...)"(Guedes, 2007: 43). No final, a actuação do administrador resultou "in a curtailing of the rights of circulation of the man accused of witchcraft." (Guedes, 2007: 43).

O segundo caso apresentado ocorreu em 1999, na comuna do Mungo, que à época estava ocupada pela UNITA. O ossoma, simpatizante do MPLA, fugiu para Luanda, e a UNITA elegeu três mulheres para ocuparem o lugar vazio do ossoma. Com o fim da ocupação pela UNITA, e quando o EstadoMPLA assumiu o controlo do município, o anterior ossoma regressou e com a ajuda do governador reassumiu a chefia da ombala e as mulheres foram destituídas. Segundo Marques Guedes, este caso constituí uma "narrative

${ }^{19}$ Sobre o papel de intermediários ver por exemplo Rouveroy van Neuwaal (1996; 1999) e Rouveroy van Nieuwaal e Rijk van Dijk (1999). 
about pragmatic power politics in a situation of exceptional need" (Guedes, 2007: 45), e uma "desvalorização positiva" "(...) as a normative fact, by the destitution carried out by the returning soma" (Guedes, 2007: 45).

Já no terceiro caso, o autor apresenta-nos uma situação que ocorria no campo de refugiados de Casseque, perto da cidade do Huambo, na qual o líder do campo era o Coordenador para a Cultura, António Pinho, um elemento do MPLA. Este elemento levava a cabo as suas funções políticas e jurídicas num modelo híbrido entre tradicionalismo e "participação popular", combinando duas modalidades de regulação da ordem jurídica local, assumindo o papel de ossoma e, por conseguinte de chefe do tribunal costumeiro, mas sujeitando a sua decisão final à participação da assembleia, ou seja, imiscuindo um princípio da participação popular no sistema tradicional de julgamentos. Segundo Marques Guedes, este modus operandi do coordenador da Cultura, resulta num "jural and judicial hybridity" (Guedes, 2007: 45).

O quarto caso desenrola-se no ano de 2002, na província de CuandoCubango. Um conjunto de sobas, liderados pelo rei Bingo-Bingo apresenta ao governador provincial oito sobas acusados de feitiçaria, pedindo a sua detenção. O governador, alegando que o caso não se consignava com a lei, recusou a sua detenção. Contudo, o governador decretou a criação de uma comissão para "julgar" o caso. A comissão julgou e condenou os oito acusados à pena de morte por fuzilamento. A execução, que ocorreu uns meses depois foi pública. Quando o facto se soube no governo central em Luanda, os membros da comissão e do pelotão, assim como o governador foram igualmente julgados e detidos.

Segundo Marques Guedes, este caso demonstra bem a ambivalência com que as autoridades angolanas lidam com as autoridades tradicionais e com as leis costumeiras. Segundo o autor, "From the State's angle, the recognitionintegration of local power figures fulfills two main functions: it allows for an extention of its implantation, even if only in indirect terms; and generates and gives off dreamy images of a return to national forms of organization(...)", por sua vez, para as autoridades tradicionais "such a recognition-integration also fills various functions, by widening its territory and implantation, augmenting its means for the exercise of power (...)"(Guedes, 2007: 47).

Este último caso conduz-nos amplamente para o cerne da discussão sobre o pluralismo legal, e das suas consequências, sobretudo no caso dos estados fracos ${ }^{20}$. Para o caso de Angola, é bastante interessante a análise que

${ }^{20}$ Tomando de empréstimo o conceito de weak state de John Migdal. 
N'Gunu Tiny produz na obra de Marques Guedes e Maria José Lopes. Este autor interessa-se por saber em que medida a actual, e a futura, Constituição angolana integra as autoridades tradicionais no seio do sistema legal angolano. Nesse sentido, começa por adiantar que a actual Constituição não faz nenhuma referência explícita às autoridades tradicionais, e que o projecto em discussão para a futura Constituição menciona o direito tradicional, ou costumeiro, como sendo parte integrante do sistema legal angolano (Tiny, 2007: 69). Por outro lado, o projecto da futura Constituição pretende incorporar as autoridades tradicionais africanas, enquanto elementos que constituem o denominado "poder local" (Tiny, 2007: 70).

No caso angolano, e seguindo a ideia do autor, a relação é hierárquica e vertical e, por conseguinte, não se trata de um sistema pluralista, no sentido nem prático nem normativo. Na verdade, segundo N'Gunu Tiny, o modelo da relação começou por ser do tipo dualista, ainda nos anos de 1980, e na actualidade é mais do tipo monista (Tiny, 2007: 77), tentando com isso o Estado angolano exercer um controlo sobre as autoridades tradicionais e sobre as próprias comunidades ${ }^{21}$.

Contudo, e como já foi demonstrado por vários autores (por exemplo Florêncio, 2005; 2008; 2009), esta relação nem sempre pende a favor do Estado, e a capacidade das autoridades tradicionais em manipularem a relação em seu favor é bastante significativa, variando logicamente de contexto para contexto, e dependendo também do carisma e da fonte de legitimidade das próprias autoridades tradicionais, tomadas no sentido singular. Deste modo, e retomando a questão do pluralismo jurídico, em muitas situações a atribuição jurídica das autoridades tradicionais, não só não constitui um complemento de democraticidade ao sistema legal nacional, como ainda o pode colocar em risco, ou constituir uma séria ameaça, nomeadamente em todos os assuntos que envolvem acusações e resolução de casos de feitiçaria, mais concretamente no que diz respeito aos sistemas punitivos costumeiros.

A questão da "suposta" democraticidade do modelo de pluralismo jurídico encontra-se fortemente relacionada com os actuais processos de formação dos estados africanos, do mesmo modo e em concomitância com o relevo dado às autoridades tradicionais. Após o indiscutível falhanço do Estado em

${ }^{21}$ Apesar do conceito de comunidade apontar para uma ampla discussão sobre o seu emprego no contexto actual africano, não se pretende aqui discuti-lo e assim emprega-se sem outro alcance senão o de sinónimo de conjunto de populações locais. 
África, nas décadas de 1970 e $1980^{22}$, a miraculosa solução surgiu nos anos 1990 com a introdução das agendas sobre a democracia, a descentralização, ou a community based development e a good governance, enquanto panaceias retemperadoras dos malefícios provocados pelo centralismo e autoritarismo estatal. No âmbito da procura da autenticidade comunal africana, as "traditional authorities was ready candidates as community representatives" (Orre, 2007: 140). Nesse sentido, no pós-guerra civil o Estado angolano tem seguido uma prática em tudo semelhante a outros estados africanos, nomeadamente, como sublinha Aslak Orre, ao caso moçambicano (Orre, 2007: 184).

No caso angolano, ainda segundo Aslak Orre, podem demarcar-se duas tendências contraditórias: a de centralização dos processos de construção do Estado, durante as décadas de 1970 e 1980, fortemente marcadas contudo pela ineficácia e incompletude do processo, ao nível nacional, devido à guerra civil e à tri-administração do território ${ }^{23}$; e a actual tendência de desconcentração e de descentralização. Segundo este autor, esta nova fase inaugura-se a partir da criação do Decreto Lei 17/99 que define os papéis e competências do governo local (Orre, 2007: 185). Na verdade, e segundo Aslak Orre, o que está em jogo nesta lei é a implementação de um processo de desconcentração dos serviços e funções estatais, aos níveis provinciais, municipais e comunais, mas sem preconizar uma descentralização efectiva do Estado, antes um reforço da autoridade e hierarquização do Estado central ao nível da globalidade do território nacional (Orre, 2007: 186).

Esta tendência de controlo e autoridade do Estado central angolano, ou mais concretamente do Partido-Estado ${ }^{24}$, que se pretende hegemónico, revela-se também no modo de relacionamento e de integração das autoridades tradicionais no actual processo de formação do Estado local. Processo marcado por uma fortíssima ambivalência, pois por um lado, assenta numa tendência dirigista hegemónica do tipo top-down, todo o processo é contro-

${ }^{22}$ De destacar, na imensa literatura sobre o assunto, a imprescindível obra de JeanFrançois Bayart, de 1989, L'État en Afrique. La politique du ventre, Paris, Fayard.

${ }^{23}$ Durante o período do conflito armado angolano, basicamente entre 1975 e 2001, o território era controlado pelos dois movimentos beligerantes, UNITA e Estado-MPLA, mas existiam bolsas territoriais que não eram controladas por nenhum destes movimentos e que, durante certos períodos "viviam" numa espécie de auto-gestão.

${ }^{24}$ Apesar das profundas alterações constitucionais de 1992, no caso angolano ainda é perfeitamente plausível a aplicação, em termos pragmáticos e de agencialidade, da noção de Partido-Estado ou de Estado-MPLA. 
lado a partir do MAT (Ministério da Administração do Território); mas com sinergias e dinâmicas muito variadas e pragmáticas ao nível local.

Por outro lado, a ambivalência também se faz notar ao nível da natureza da própria aliança estratégica entre Estado e autoridades tradicionais. Se por um lado o Estado tenta instrumentalizar as autoridades tradicionais enquanto funcionários administrativos e partidários, ao nível local, como parte do processo de extensão, consolidação e legitimação para as populações, sobretudo rurais, por outro lado, como sublinha Aslak Orre,

"the traditional authorities are also themselves suffering (...) a legitimacy crisis. (...) Due to enormous demographic changes associated with the war refugees and urbanization, traditional authorities's power is waning. Many are also afraid of the consequences of raising their heads as traditional authorities, due to previous alliances with UNITA during the war" (Orre, 2007: 191).

A referida tendência monista com que o Estado angolano pretende enquadrar as autoridades tradicionais nacionais fica bem expressa num relatório de 1996, realizado a pedido do MAT, e coordenado por André Sunda Dialamikua. Neste relatório, assume-se claramente a necessidade de enquadrar as autoridades tradicionais angolanas debaixo da alçada da administração central, pois como afirmam os autores,

“(...) a necessidade de enquadrar, integrar e modernizar as Autoridades Tradicionais, reconhecê-las, respeitá-las e torná-las mais adequadas e operacionais, constitui um assunto ao qual a política administrativa e o saber científico nacional não podem, nem devem escapar." (Dialamikua, 1996: 1).

Aqui fica bem expresso que, o reconhecimento e o respeito que o Estado deve prestar às autoridades tradicionais concretiza-se nesse cenário de integração e enquadramento. Por outro lado, a leitura do relatório também nos revela um aspecto interessante, e esquecido pela generalidade da literatura sobre o tema, nomeadamente sobre o reconhecimento dos conflitos existentes, ao nível local, entre as autoridades tradicionais e os coordenadores dos Comités do Bairro ${ }^{25}$. Pode então ler-se neste relatório,

${ }^{25}$ Estrutura do partido MPLA e do Estado, um pouco à semelhança dos secretários de bairro, em Moçambique. Sobre o conflito entre as autoridades tradicionais em Moçambique e os secretários de bairro, cf. Florêncio (2003; 2005). 
"O caso da contenda, em alguns pontos do País, entre os coordenadores dos Comités de Bairro e os sobas é clarividente nos nossos dias de pósindependência. Reconhece-se que, durante a luta contra a ocupação colonial, as Autoridades Tradicionais desempenharam um papel activo e positivo, colaborando com as forças nacionalistas. Mas proclamada a independência e projectada a reconstrução nacional as chefias tradicionais não foram reconhecidas e tidas em conta para a administração local, sendo substituidas pelos Coordenadores dos Comités de Bairro, muitas vezes desconhecidos ou estranhos da colectividade, que a ninguém representavam, mas a quem, por medo deviam obedecer" (Dialamikua, 1996: 3).

Contudo, é só a partir de 2000 que a questão da integração das autoridades tradicionais, e sobretudo a questão do poder local e da descentralização, começam a ganhar especial relevo, quer nas agendas políticas estatais quer da sociedade civil. Nesse sentido, saliente-se o relatório de 2001, elaborado pelo Grupo Técnico para as Questões Jurídico-Legais, apresentado ao Conselho de Ministro, em Setembro desse mesmo ano. Denominado de Plano Estratégico da Desconcentração e Descentralização Administrativas: o Poder Local Autárquico e o Poder Tradicional em Angola, este relatório apresenta um conjunto de propostas com vista a traçar uma estratégia de organização da administração ao nível local, municipal e comunal.

Logo na sua Introdução, os autores justificam tal estratégia com base em dois pressupostos de enorme significado. Por um lado, a constatação do falhanço das anteriores iniciativas legislativas, nomeadamente dos decretoslei 17/99, 27/99 e do Decreto-Executivo 80/99. Em segundo lugar, e de modo bastante relevante, os autores justificam a necessidade deste plano estratégico precisamente a partir das debilidades do Estado central, num contexto ainda marcado pela guerra civil, pois como afirmam "A situação de guerra e de instabilidade militar reflecte-se imediatamente, na debilidade geral do Estado e da sua administração, estruturação, funcionamento, autoridade, coesão e eficiência" (Grupo Técnico para as Questões Jurídico-Legais, 2001: 5). Ou seja, o processo de construção do Estado local deve constituir uma prioridade dada a ineficácia, incapacidade e falta de legitimidade do Estado central em controlar administrativamente a totalidade do território e da população.

Os autores da proposta defendem um processo de construção do Estado local gradualista, assente em 3 fases: uma fase inicial de desconcentração administrativa, seguida de uma fase de descentralização administrativa, e 
posteriormente da criação de autarquias. Nas suas próprias palavras “ (...) um programa global, faseado e gradualista de, num primeiro momento, reforma da administração local do Estado, e, depois, de institucionalização de um poder local autónomo autárquico e tradicional" (Grupo Técnico para as Questões Jurídico-Legais, 2001: 10). O que se concebe como poder local autónomo autárquico e tradicional não é cabalmente definido, o que pode significar que, em 2001, ainda não existia uma ideia clara do lugar e tipo de papel que as autoridades tradicionais poderiam jogar neste processo. Nesta aparente confusão, os autores defendem que "o princípio da autonomia local não pode ser sinónimo de autarquias locais mas deve, no plano orgânico, ter como manifestação não só as autarquias locais mas, também as instituições organizatórias tradicionais" (Grupo Técnico para as Questões Jurídico-Legais, 2001: 14-15). Aliás, os autores enfatizam mesmo que as autoridades tradicionais são,

"uma das manifestações da autonomia local e desde logo, como um elemento estruturante e qualitativo do nosso conceito de poder local (...). O reconhecimento do poder tradicional como uma instituição autónoma é um imperativo do princípio do Estado democrático de direito aplicado a uma realidade especifica como a nossa." (Grupo Técnico para as Questões Jurídico-Legais, 2001: 29).

Nesse âmbito, o relatório defende que as competências das autoridades tradicionais deve confinar-se ao espaço territorial-administrativo das povoações e comunas, e que as suas funções se enquadrem na,

“administração de bens próprios, na promoção do desenvolvimento e da actividade produtiva; abertura e manutenção de vias de acesso; recenseamento da população; protecção do meio ambiente, do património físico e cultural; divulgação e implementação das decisões dos órgãos autárquicos e do Estado, (...)"(Grupo Técnico para as Questões Jurídico-Legais, 2001: 30).

Por este relatório pode depreender-se que para os autores as autoridades tradicionais, assim como as autarquias, fariam parte desse poder local, a ser institucionalizado ao nível das comunas e das povoações. No entanto, o plano estratégico é bastante ambíguo, ou pelo menos bastante impreciso, na definição do que seria o "poder local autárquico e tradicional". Muito mais 
preciso é o texto de Carlos Feijó, produzido ainda em 2000. Nesse texto o autor precisa o que entende por poder local, diferenciando as relações entre o Estado, as autarquias e as autoridades tradicionais.

Essencialmente centrado sobre as questões da descentralização, neste texto de Carlos Feijó interessa preferencialmente retirar a noção de poder local, pois ela virá a influenciar alguma da produção legislativa consequente, até pelo papel do autor nessa mesma produção. Desde logo, o autor refere que o poder local se encontra relacionado com a auto-determinação, e que ele deve ser constituído por órgãos representativos das populações, e que o poder local se diferencia da descentralização administrativa, por exemplo,

“(...) o poder local não é operacionalizado por qualquer descentralização territorial. É necessário que a descentralização administrativa seja encarada no plano jurídico e político, isto é, não é, pelo facto de, por exemplo, existirem autarquias locais, no plano jurídico, que se deve aferir a existência de um verdadeiro poder local. É necessário, ainda, apurar se no plano político, os órgãos das autarquias locais são, livremente, eleitos pela população locais" (Feijó, 2000: 3).

Avança depois para uma definição de poder local, que,

“deve ser definido como aquele poder político originário ou derivado exercido, nos termos da lei, a nível das comunidades locais através de órgãos descentralizados, de instituições organizatórias tradicionais e de outras formas de participação democrática das população visando a satisfação dos seus interesses próprios" (Feijó, 2000: 3).

Carlos Feijó apresenta assim uma visão autonómica do poder local, englobando nele as autarquias, as autoridades tradicionais e outras organizações de base, como as comissões de moradores, por exemplo (Feijó, 2000: 4). Neste contexto, a visão do autor poderia definir-se mais no sentido de uma integração dualista das autoridades tradicionais, pois o próprio autor define este tipo de poder local como "anterior do Estado ou até mesmo desenvolver-se fora dele", e ainda de que esta instituição deveria ter um reconhecimento constitucional, mas que "trata-se de apenas de reconhecimento de uma realidade pré e extra-estadual (...)" (Feijó, 2000: 4). 


\section{As autoridades tradicionais e o pluralismo jurídico no munícipio do Bailundo}

No município do Bailundo, à semelhança do que sucede em Angola desde 2003, as autoridades tradicionais do antigo reino do M'Balundu têm vindo a ser incorporadas no processo de formação do Estado $^{26}$, num processo semelhante ao que se desenrolou durante o período colonial, e que, devido às suas características actuais se pode apelidar de uma incorporação do tipo

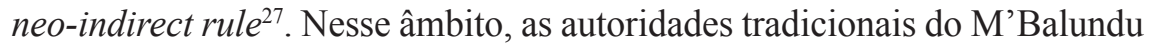
são na actualidade chamadas a desempenharem um conjunto de tarefas, tais como o controlo e distribuição do fundo fundiário comunitário e dos lugares sagrados; o controlo do assentamento das populações deslocadas durante o conflito; a mobilização das populações dos quimbos (aldeias) para os programas estatais nas áreas da saúde e educação; o recenseamento da população; registo dos nascimentos e óbitos; a colecta de certos impostos municipais (pequenos comerciantes dos mercados); licenças de caça e pesca; licenças de actividades comerciais, etc ${ }^{28}$.

No entanto, e à semelhança do que sucedia no período colonial ${ }^{29}$, de entre as funções que na actualidade mais impacto têm na vida das populações destaca-se, desde logo, a função jurídica e de manutenção da ordem, dado que o município do Bailundo ainda não tem a estrutura judiciária e judicial a funcionar na plenitude, como sublinha o Procurador Municipal, Gabriel Caála (in EBai2007-05). Neste caso, existe um juiz municipal mas o tribunal ainda não funciona, por falta de mais juízes. Também a PIC (Polícia de Investigação Criminal) só existe na sede do município, na vila do Bailundo, sendo que nas comunas só existe mesmo o corpo regular de Polícia. Ao nível da Procura-

${ }^{26}$ Para um entendimento mais profundo da história do reino do M'Balundu, e sua articulação com o Estado colonial e com a actualidade cf. Florêncio (2009).

${ }^{27}$ Sobre a pertinência desta designação e sua actualização ao caso do Bailundo, cf. Florêncio (2008; 2009).

${ }^{28}$ Além destas tarefas de cariz administrativo, as autoridades tradicionais são muitas vezes envolvidas, voluntariamente ou não, em processos político-partidários, nomeadamente na mobilização das populações para comícios e outras actividades dos principais partidos políticos (MPLA e UNITA).

${ }^{29} \mathrm{Na}$ actualidade, e ao contrário do que sucedia durante o período colonial, as autoridades tradicionais não participam nas tarefas de cobrança do imposto de palhota (não existe actualmente um imposto nacional), nem de controlo da mão-de-obra africana para o trabalho forçado (que foi formalmente abolido ainda durante o período colonial, em 1964). 
doria só existe Procurador na sede do município, tendo este que se deslocar às sedes de comuna sempre que é solicitado. Uma vez que existem mesmo municípios que não têm Procurador, como no caso do Mungo e Cunduimbai, é o Procurador do Bailundo que tem que se deslocar a estes sítios. Contudo, e ainda segundo o Procurador do Bailundo, a Procuradoria tem imensas dificuldades e problemas com transportes, e por essa razão é a polícia desses municípios quem traz os casos ao Bailundo para aí serem julgados.

Olhando como exemplo para a comuna de Luvemba, as autoridades tradicionais acabam por desempenhar um papel jurídico fundamental, sobretudo ao nível comunal, estando, tal como no passado colonial, autorizadas a resolver pequenos casos nos seus tribunais de ecanga $a^{30}$, tais como adultérios, pequenos furtos, feitiçaria, etc. Outro tipo de crimes, como violações, crimes de sangue, agressões violentas e homicídios, devem ser encaminhados para a administração comunal, que, por sua vez reencaminha para a polícia comunal. Como ao nível comunal não existe Procuradoria, a polícia comunal reenvia o caso para o Procurador Municipal (in EBai2004-03).

Contudo, a separação de competências jurídicas entre a Procuradoria e as autoridades tradicionais não é muito clara, e o próprio procurador assume que muitas vezes as autoridades tradicionais exacerbam as suas competências, julgando crimes de homicídio, ou outras ofensas de sangue, sem sequer participarem à polícia comunal, o que demonstra bem a "fraqueza" do Estado neste domínio. Estes casos de homicídio não-participados em geral estão relacionados com acusações de feitiçaria, como sublinha o epalanga ${ }^{31}$ da ombala de Chilumbe, "Agora matar pessoa vai na polícia, matar assim de facada, se for de feitiçaria fica mesmo no soba" (in EBai2007-06). Uma vez tomado conhecimento destas situações, a Procuradoria intervém e pode processar o ossoma responsável, como aliás se constatou pelo quarto exemplo apresentado por Marques Guedes. Mas esta medida correctiva é mais formal que real, pois na prática isso ainda não sucedeu com nenhuma autoridade tradicional do Bailundo.

No entanto, e para a generalidade dos casos, os olossoma respeitam as suas competências e limites, e enviam para a polícia comunal os casos mais graves, que por sua vez os encaminha para a PIC e para a Procuradoria.

${ }^{30}$ Termo Umbundo que designa este tipo de tribunais das autoridades tradicionais.

${ }^{31} \mathrm{O}$ epalanga é um dos cargos mais importantes da estrutura de poder tradicional do M'Balundu, em geral um irmão ou sobrinho do ossoma. 
Por outro lado, e como adianta o procurador municipal, existem igualmente situações inversas, em que a própria Procuradoria municipal encaminha determinados casos para as autoridades tradicionais (in EBai2007-05).

Os casos de feitiçaria continuam a constituir a grande maioria das acusações apresentadas nos tribunais das autoridades tradicionais, e só podem mesmo ser resolvidos com recurso ao processo de julgamento tradicional, que envolve uma complexa teia de processos, desde a adivinhação e consulta a oráculos, à utilização de ordálios.

Sobre a feitiçaria, ou mais concretamente sobre o oculto em África, existe é claro todo um conjunto de concepções, e de narrativas ${ }^{32}$. Em muitos exemplos empíricos, o soberano é representado como um poderoso regulador da ordem, daí as suas funções jurídicas e legislativas, mas também um regulador do universo mágico-religioso e um intermediário com os espíritos dos seus antecessores, nomeadamente do falecidos soberanos. Acredita-se, assim, que o soberano é possuidor, por essa intermediação, de capacidades específicas de usar as forças do oculto, quer em seu proveito próprio quer da própria sociedade. Nesse sentido, a sua ambiguidade joga-se igualmente nessa espécie de liminariedade entre ser um fazedor de ordem e um fazedor de desordem. Pode ser mesmo um poderoso onganga, feiticeiro, ou de tal ser acusado e temido, como diz o ossoma Jino Kaiangula.

"o soma nunca pode ser um quimbandeiro"33, (...) Antigamente os sobas tinham os seus quimbandeiros fixos nas ombalas, mas agora isso já não se verifica. Os quimbandeiros existem, estão nas aldeias e ainda praticam, mas nas ombalas já não. Mas agora o soba pode ser acusado de feitiçaria, se for acusado pela população era encaminhado ao soba grande para ser julgado. [...] se for acusado ele é julgado pelos seus componentes que constitui a ombala [elengo]. O mwekalia convoca os outros e esses é que são de direito de julgar o soba. Se a acusação é concreta então é substituído. Isso nunca aconteceu aqui. Se alguém quiser enfeitiçar o soba isso não acusa [não resulta]. O ser soba mesmo é que impede que chegue o feitiço" (in EBai2004-04).

${ }^{32} \mathrm{O}$ termo oculto serve para designar todas as forças espirituais, em geral espíritos, familiares ou não, e sua capacidade de intervir na vida dos humanos, seja uma intervenção protectora ou maléfica. Sobre este tema existe uma vasta bibliografia, desde o clássico de Evans-Pritchard, aos mais recentes trabalhos de Peter Geshiere, Harry West, Alcinda Honwana, etc.,)

${ }^{33} \mathrm{O}$ mesmo que ocimbanda, ou seja curandeiro-adivinho. 
$\mathrm{Ou}$, como defende o ossoma Adolfo Chitoma, no passado os olossoma tinham poderes mágicos, pois "os sobas podem ter feitiço, sim. Nos tempos passados acontecia isso, o soba dizia mesmo "você sai daí", senão acontecia mesmo qualquer coisa”. Esse poder mágico era uma imanência dos espíritos dos antepassados, como diz o próprio ossoma " "antigamente acontecia isso, sim, vinha dos antepassados". Mas, na actualidade as autoridades tradicionais foram perdendo essa capacidade mágica, e "hoje não, hoje não. Hoje o soba é enfeitiçado também. Antigamente metia medo quando via o soba" (in EBai2004-06).

No caso de uma acusação de feitiçaria sobre uma "pessoa comum", o processo decorre segundo um modelo que mantém muitos dos traços do passado, e que se manteve quer na época colonial quer actualmente. Em primeiro lugar, a pessoa que se julga "enfeitiçada", ou um familiar desta, apresenta o caso na sua autoridade tradicional. Esta designa um quimbandeiro que irá proceder à adivinhação do infortúnio. Os processos de adivinhação são múltiplos, como relata o quimbandeiro Fernando Adonho Mbonga, segundo o qual "Uns adivinham pelo espelho, mete o espelho e adivinha pelo espelho, no espelho pode surgir a pessoa que está a enfeitiçar, o feiticeiro. Outros é pela caneca, na água que está dentro da caneca vê a doença, ou quem está a provocar a doença" (in EBai2004-09) 34. Uma vez detectada a fonte do infortúnio, ou seja o agente maléfico (o onganga), o quimbandeiro, reporta o caso à autoridade tradicional, que manda reunir o tribunal, já na presença do respectivo "acusado". Se a acusação se reportar a um acto grave de feitiçaria, como por exemplo envolvendo mortes, então o acusado pode ser submetido a um ordálio especial, o umbulungu $u^{35}$. Segundo Jino Kaiangula,

“tem métodos tradicionais para resolver esses casos. Utilizávamos galinhas, tem os seus métodos. Caso o acusado seja utente do que é acusado [seja feiticeiro] então o indicado animal sofreria algo. Esses casos eram resolvidos a partir dos quimbandeiros. Quem manda ir no quimbandeiro éo soba. [antigamente] utilizava-se um medicamento tradicional, o umbulungu. A pessoa que fosse acusada tomando aquele medicamento se fosse mesmo feiticeiro morria. Hoje não, onde se faz é mais na ombala grande, na ombala

${ }^{34}$ Assim, pode adivinhar-se o tipo de infortúnio, ou de doença, mas igualmente o agente causador, se pessoa, feiticeiro, ou se algum espírito.

${ }^{35} \mathrm{O}$ umbulungu é um veneno feito a partir da casca de uma árvore, e o processo é conhecido apenas por certos experts, tais como alguns dos quimbandeiros locais de renome. 
M'Balundu. [...] os portugueses não proibiram isso, porque eram práticas tradicionais nossas que encontraram. [...] Quando há um caso, o acusado vai ao soba, depois é que vai ao quimbanda que pratica esses actos" (in EBai2004-04).

Na ombala de Janjo o processo de "procura" de onganga (feiticeiro) é muito semelhante ao relatado anteriormente, como relata um dos membros do elengo ${ }^{36}$ do ossoma,

"no caso de feitiço, aquela pessoa [o acusador] não tem provas concretas porque é uma coisa invisível, não dá para acusar assim directamente, não se pode indicar que fulano tem tal feitiço. Então é preciso chamar o quimbanda, é ele que conhece a matéria de feitiço, ele sabe muito bem quem tem. Aquele que enfeitiçou também sabe muito bem que aquela pessoa que está doente tem feitiço. Esse que enfeitiçou tem que arranjar medicamento que é para curar o outro. (...) Sim, aqui existe umbulungu, quem faz é o quimbanda. Quando a pessoa morrer é porque é feiticeiro sim" (in EBai2004-07).

Sobre o uso do umbulungu, que como se disse é um ordálio de veneno, existe uma profunda ambiguidade. Muitos defendem que o umbulungu que se usava no período pré-colonial já não é usado directamente nos seres humanos, mas sim em animais, como por exemplo nas galinhas, numa espécie de processo de transferência ou da utilização de um "bode expiatório" que expie as penas humanas, como defende o ossoma de Chilume, segundo o qual "Antigamente havia [de matar], mas agora viraram e já não há mais esse umbulungu de tomar [veneno]. Do tempo colonial para cá já não. Tem mais outro umbulungu que não é de tomar" (in EBai2007-06). O mesmo afirma o ossoma de Chilala, Mário Jorge Calesse,

"Hoje no umbulungu eles apanham galinha, ou então um salalé, aqueles mesmo da mata. Então fazem a experiência aí, fazem isso em nome de um [acusado], depois esperam o resultado, depois fazem em nome do outro, esperam resultado. Lá onde houver problemas e fizerem na minha vez e houver sinais então significa que eu sou culpado. Mas se não houverem sinais significa que está ileso. A experiência faz-se assim. No passado era mesmo

${ }^{36}$ Conselho de notáveis do chefe, ou do rei. 
de beber e humanamente vitimava pessoas. Mesmo se ele era feiticeiro, mas depois disso ele morre. Mas agoram viram que não e é só experimentar numa coisa e depois os sinais aparecem, em vez de dar numa pessoa para depois morrer. Pode dar-se numa galinha, ou numa outra coisa, depois os sinais vêm e vê-se que o fulano é feiticeiro, e não dá no próprio indivíduo porque depois morre." (in EBai2007-08).

Contudo, o mesmo informante não deixa de sublinhar que,

“ (...) no tempo dos portugueses era mesmo de fazer experiências nas galinhas e outras coisas, mas nesse tempo de guerra de agora, como normalmente é que havia mais intensidade de feitiçaria é que se aplicava directamente nas pessoas. Agora regressou-se ao passado, já não se pode aplicar nas pessoas, tem que ser nas galinhas. Nesse tempo de guerra na havia uma acalmia que as pessoas pudessem trabalhar num único sitio, então era lá mesmo onde houvera esse problema de feitiçaria, então aplicava lá mesmo" (in EBai2007-08).

No entanto, vários informantes indicam a realização secreta do $u m b u$ lungu ainda hoje, sobretudo na ombala real do $\mathrm{M}^{\prime} B$ alundu ${ }^{37}$. Contudo, por estes dois depoimentos pode perceber-se que a prática do umbulungu em seres humanos acusados de feitiçaria, apesar de rara e esporádica, ainda pode acontecer em certos casos. A ser inteiramente verdade, tal constitui uma óbvia inconstitucionalidade, pois na prática a administração de um veneno num ser humano corresponde a uma quase sentença de morte, ou semi-sentença, e a prova de que a discussão sobre as virtualidades do pluralismo jurídico afigura-se, nas práticas, muito mais complexa e difícil, do que na sua concepção teórico-ideológica.

Assim, e no que respeita à tipologia de penas que estes tribunais de ecanga podem aplicar, pode afirmar-se que a situação é ainda bastante confusa, e mesmo controversa, até porque as autoridades tradicionais alegam e reclamam da "tradição" para aplicarem essas penas, ou, até como se viu anteriormente, dos ordálios de feitiçaria, o umbulungu, tal como defende por exemplo, o ossoma de Lunge, segundo o qual,

\footnotetext{
${ }^{37} \mathrm{Ou}$ seja no palácio real, na capital do reino, onde se estabelece a corte do rei, o ossoma inene.
} 
"Quem matar, é matar também. Ou então, se ele tiver família forte entrega pessoa vivo e uns tantos cabeças de gado para pagar a vida do outro. E essa pessoa que vai ser entregue é logo cravado a $\imath^{38}$. Feiticeiro é diferente, depende. Os velhos fazem prova própria. Depois, se a pessoa for mesmo verdade feiticeiro era queimado ou botado na água. Afogado, é. Essa prova é o umbulungu. Quem sabe mesmo fazer é o quimbandeiro. O quimbandeiro é que faz a prova própria, e todo o mundo está aí a ver se é mesmo o próprio. Se ele ficar ai e perder a razão então ele é amarrado e metido na água. Ou arranjar lenha, ele fica ali sentado e queimá-lo. Mas é problema, se ele não é e saltar nesse fogo para fora, aquela família que o acusou esses também são presos no soba. Esses dão boi, e dá uma pessoa que vai render o próprio [o que foi falsamente acusado]. Porque se ele é o próprio feiticeiro morre com o fogo, mas se não for quando vai rebentar, salta dai do fogo. Se ele for na verdade, fica ai assim" (in EBai2004-06).

Mas como se disse anteriormente, estas afirmações não são pacíficas, e são desmentidas por muitos, incluindo o próprio rei Ekuikui IV, Augusto Katchiopololo, que afirma que,

"O umbulungu até hoje está a fazer-se. Só se faz na ombala do rei. Não se pode fazer fora. $O$ umbulungu de matar pessoa já não se faz mais. Agora o umbulungu é só de mostrar um sinal de que este aqui tem culpa. Nos tempos anteriores, esse que morre [de umbulungu] é porque tem culpa, foi julgado pelo rei, foi julgado pelos sobas, e essa culpa será mesmo de que esse homem não merece viver, tem que morrer. Então o rei é que dá a admissão. Mas isso passou já nos tempos. O português quando veio proibiu que se matassem pessoas, mas com o andar dos tempos fomos vendo que os portugueses levavam pessoas, castigavam e morriam, e isso na mente dos sobas fez-nos confusão, 'como é que ele nos proíbe de matar e arrasta pessoas para a morte?" (in EBai2004-08).

Em qualquer dos casos, a realização de um ordálio de umbulungu em princípio só pode ser determinado pelo ossoma inene, como sublinha o epalanga de Chilumbe "Outras coisas eles podem decidir [os sobas] mas

\footnotetext{
${ }^{38}$ No período anterior à dominação colonial os castigos por homicídio em geral resultavam no empalamento do culpado.
} 
há coisas que aqui [na ombala] não podem fazer, tem que ir lá na ombala grande, é a prova do umbulungu. Umbulungu tem que ser só feito a partir da ombala grande." (in EBai2007-06).

Mas nem todas as penas têm este quadro jurídico, e mesmo nos casos de feitiçaria, estas penas só são aplicadas quando o caso envolve mortes. No geral, as penas envolvem indemnizações pecuniárias, ou em géneros, "se alguém bateu no outro, paga um porco, ou um cabrito, ou outro animal, do valor da ofensa. (...) Dinheiro também usa, por exemplo se for preciso pagar os tratamentos ao outro. (...) Se matar alguém vai na polícia." (in EBai2004-07). Se for caso de adultério, por exemplo, o caso é diferente, "a mulher não tem culpa, o acusado sabe muito bem que essa mulher é alheia, então devia ter respeito pelo dono da esposa. O homem que é dono da esposa não vai largar a mulher, por causa dos filhos e fica com a mesma mulher. Então o acusado é que paga, o que o elengo decidir. Tudo vai cair sobre o acusado" (in EBai2004-07).

A apresentação de uma acusação também envolve uma contribuição ao tribunal, em geral em géneros, por exemplo nesta ombala de Janjo,

"Quem vem apresentar um caso abre a assembleia e dá qualquer coisa para a abertura e também para o fecho. Pode ser galinha, porco. O tal que apresenta queixa terá que dar coisas que é para o tempo que fizer aqui as pessoas precisam de comer, precisam de beber, então precisa de dar fuba, precisa de dar galinha e também a bebida, tem que ser um garrafão." (in EBai2004-07).

Num julgamento tradicional existe uma forte componente de participação popular, pois toda a comunidade pode participar, e os membros do elengo executam tarefas de "advogados de acusação" e de "advogados de defesa". A decisão e pronúncia final cabe à autoridade tradicional reinante no tribunal, o ossoma ou ossoma inene, no caso dos julgamentos na ombala real do M'Balundu. No entanto, este modelo de julgamento difere bastante de ombala para ombala. Desde logo no local da sua realização, por exemplo em quase todas as olumbalas o julgamento realiza-se no ondjango ${ }^{39}$, ao passo que na ombala real os julgamentos realizam-se no terreiro exterior à entrada.

${ }^{39} \mathrm{O}$ ondjango é uma cabana redonda com duas entradas, uma para os membros da ombala e o outra para as visitas, e é um dos lugares mais sagrados e míticos de todo o espaço 
O processo difere também na importância que em cada ombala é atribuída aos membros específicos do elengo. Por exemplo, nos julgamentos realizados na ombala de Chijamba cabe ao tchinduli $^{40}$ anunciar o veredicto e as penas a aplicar (in EBai2004-04). Por contra, este não é o entendimento que faz a maioria dos olossoma e, por exemplo, de acordo com o ossoma Adolfo Chitoma, na sua ombala de Lunge, quem anuncia o veredicto final do tribunal e as penas é o mwekalia $^{41}$ e não o tchinduli $^{42}$. Para sublinhar ainda mais estas divergências, na ombala de Janjo esta função é desempenhada pelo ndaka $^{43}$ (in EBai2004-07).

Importa sublinhar ainda que, em certa medida, a estrutura dos julgamentos, e até mesmo o tipo de casos e de acusações presentes nestes tribunais das autoridades tradicionais, ou que o Estado "autoriza" que aí se resolvam, continuam muito semelhantes aos do período colonial, destacando-se largamente as acusações de feitiçaria, roubo, adultério e agressões físicas.

No caso do M'Balundu, e ao contrário por exemplo do que sucede em Moçambique, nomeadamente na zona centro deste país ${ }^{44}$, estes tribunais das autoridades tradicionais do M'Balundu não reúnem periodicamente num determinado dia, mas sim de modo aleatório, ou sempre que seja necessário, como afirma Adolfo Chitoma,

"Depende quando calhar o caso, então é que vamos sentar. Não, não, não há dias para isso. Há coisas graves que não pode esperar amanhã ou depois. É logo resolvido porque às vezes há-de sair alguém que vai preso. $O$ que pode esperar, que pode dar mais cinco dias ou quê é quando dá coisa de feitiçaria, mas quando dá porrada isso não pode esperar, na mesma altura é chamar o indivíduo que deu porrada e é logo julgado, se o caso não der [se não se puder resolver na ombala, caso haja um homicidio por exemplo] é logo levado ao Estado [à polícia ou à Procuradoria municipal]" (in EBai2004-06).

da ombala, exceptuando os akokotos, pois trata-se de um lugar de reunião, de assembleia, de produção da palavra, de consensos e de decisões colectivas.

${ }^{40} \mathrm{Um}$ dos conselheiros do ossoma e membro do elengo,

${ }^{41} \mathrm{O}$ mwekalia é a figura mais importante dos elengo, são estas figuras que nomeiam os ossoma, e que podem mesmo destituí-los. O mesmo sucede no elengo real do ossoma inene.

42 Entrevista EBai2004-06.

${ }^{43}$ Outra figura do elengo.

${ }^{44}$ cf. Florêncio (2003; 2005). 
Dos contactos mantidos com a população local do município nos trabalhos de campo, pode dizer-se que a existência deste pluralismo legal é vista como bastante positiva pela população, que realça o respeito pela sua "cultura" e o facto do Estado e do direito constitucional não conseguirem resolver problemas fundamentais do seu quotidiano, como por exemplo os casos relacionados com o oculto, como a bruxaria e a feitiçaria. No entanto, é preciso sublinhar que o chamado direito tradicional, costumeiro ou consuetudinário, e o direito constitucional colidem e sobrepõem-se em certas áreas, entrando mesmo em contradição, facto constatado numa entrevista com jovens do Bailundo (in EBai2007-04). Estes jovens realçam duas áreas bastante sensíveis de colisão entre o direito tradicional e o direito nacional, tais como os castigos físicos e a prova de umbulungu, e o direito da mulher e da família. No primeiro caso, é evidente que o oráculo do veneno do umbulungu, assim como os castigos físicos infligidos aos acusados de feitiçaria, são profundamente inconstitucionais, e só acontecem com o beneplácito das autoridades estatais. No segundo caso, o direito tradicional restringe direitos das mulheres angolanas, que estão consagrados na Constituição.

Por seu lado, o Estado está consciente desta discrepância, e mesmo da inconstitucionalidade de certas práticas e sentenças dos tribunais das autoridades tradicionais, pois como sublinha o próprio Procurador municipal do Bailundo,

"Nos tribunais tradicionais existem processos e penas que são inconstitucionais, como por exemplo os que são usados para os casos de feitiçaria, como o umbulungu e o lomanjo ${ }^{45}$, no caso do umbulungu as pessoas que o tomam morrem na maior parte das vezes.(...) Por vezes são as próprias famílias que denunciam estas provas tradicionais junto da polícia. A polícia depois vai investigar. Por exemplo no Mungo, numa das ombalas da comuna de Cabuengo o soba autorizou o umbulungu, a pessoa morreu, ele [o ossoma] foi julgado e preso no Huambo." (in EBai2007-05).

Estas incongruências derivam da inexistência de um quadro jurídico nacional que regule as competências e atribuições dos tribunais das autoridades tradicionais nas questões jurídicas, proposição esta que o próprio

${ }^{45} \mathrm{O}$ lomanjo é um pequeno bastão que serve para apertar os tornozelos e o crânio dos acusados de actos de feitiçaria, e que acabam por ficar nessa situação vários dias de castigo. 
Procurador defende. O que é de realçar é que, na actualidade, quer o Estado angolano quer as autoridades tradicionais continuam a seguir as representações que têm das competências que estas últimas desempenhavam para o Estado colonial.

Finalmente, parece igualmente relevante sublinhar que a autoridade e até mesmo a legitimidade jurídica das autoridades tradicionais pode estar em declínio, sobretudo entre os jovens urbanizados, como se constatou na supracitada entrevista, uma vez que os jovens hoje preferem dirigir-se aos tribunais das autoridades tradicionais não por serem estes mais legítimos, mas sim porque,

"têm mais medo da polícia, porque prende, e os sobas e os sékulus não, ai basta pagar qualquer coisa e a pessoa vem embora. (...) Nos quimbos os jovens seguem os mais velhos, aí não há polícia, não há Estado, e os jovens estão mais oprimidos pela familia, pelos mais velhos. Então aprendem desde novos a respeitar e a obedecer aos mais velhos, e aos sobas e sekulus" (in EBai2007-04).

\section{Conclusão}

Neste artigo pretendeu-se demonstrar, a partir do estudo de caso do município do Bailundo, em Angola, que a discussão sobre o pluralismo jurídico em África está intimamente relacionada com a discussão sobre o papel das autoridades tradicionais na construção, ou reconstrução, dos estados independentes africanos.

À semelhança do que sucedeu no período colonial, os estados independentes utilizam as autoridades tradicionais enquanto "extensões" administrativas, sobretudo nos espaços rurais, de molde a exercerem um controlo mais eficaz e legítimo sobre o território e sobre as populações. Esse modelo de administração por via das autoridades tradicionais ficou conhecido no tempo colonial por indirect rule. Na actualidade, apesar das continuidades que apresenta o modelo de incorporação das autoridades tradicionais nas administrações locais, existem mudanças significativas, uma vez que estes actores locais desempenham novas tarefas administrativas, e simultaneamente, participam nos jogos políticos locais, sendo assim mais correcto apelidar esse modelo de neo-indirect rule. 
Como se demonstrou a propósito do colonialismo português, a existência de um pluralismo jurídico consubstanciava a existência de dois tipos de sociedades separadas, a sociedade colonial e as sociedades colonizadas, ou indígenas. Em que a manutenção das ordenações jurídicas indígenas não preconizava qualquer tipo de respeito, ou aceitação dos seus "costumes", mas sim uma subordinação ideológica, e, nas práticas, uma incapacidade do Estado colonial português e das administrações, em gerir e controlar a totalidade dos seus territórios e das populações colonizadas.

$\mathrm{Na}$ actualidade, e sobretudo no pós-guerra civil, o Estado angolano iniciou em 2002 um processo de reconstrução e consolidação, ao nível provincial e municipal, no qual as autoridades tradicionais jogam um papel fundamental, em termos políticos, administrativos, e jurídicos. Viu-se que esse processo se encontra marcado por continuidades face ao processo colonial, mas também por rupturas. De entre as continuidades, talvez que a mais saliente seja mesmo a continuação do papel jurídico que as autoridades tradicionais desempenham.

Nesse capítulo, defendeu-se que o Estado angolano não conseguiu ainda estabelecer um quadro legislativo nacional que enquadre os tribunais das autoridades tradicionais, apesar de definir genericamente as suas competências que, aliás, são basicamente as mesmas do período colonial. Por outro lado, o próprio Estado ainda não conseguiu definir uma linha de orientação concreta, tendo ao longo deste tempo alternado entre uma moldura institucional mais do tipo monista e outras vezes mais do tipo dualista. $\mathrm{Ou}$ seja, na verdade pode dizer-se que na teoria, o Estado angolano tem tentado impor uma moldura legal que enquadre um modelo monista. Contudo, as práticas locais, em face das próprias incapacidades do Estado e seus agentes, e das próprias dinâmicas e interesses dos actores locais envolvidos, concretizam mais uma moldura dualista, na qual o Estado e o regime legal nacional muitas vezes acabam por ser adulterados, ou mesmo obliterados, para certos sectores da população municipal.

Foi precisamente ao nível dessas mesmas práticas que o artigo se centrou, a partir do caso das autoridades tradicionais do reino do M'Balundu, no município do Bailundo. As práticas jurídicas que aqui são reveladas apontam para um conjunto de conclusões importantes:

- Em primeiro lugar, destaca-se o facto de que, no entendimento dos principais actores sociais envolvidos, as autoridades tradicionais e os representantes do Estado (por exemplo os funcionários da Admi- 
nistração Municipal, e o próprio Procurador Municipal), os quadros jurídicos e os modelos de actuação significantes são ainda os que perduram desde o período colonial. Quer ao nível da tipologia de casos que se podem julgar nos tribunais das autoridades tradicionais, quer ao nível da tipologia penal que estes aplicam.

- Em segundo lugar, as práticas demonstram hoje, tal como no passado colonial, uma forte incapacidade das administrações estatais locais em controlarem estes tribunais e que neles se julgam casos para os quais não estão autorizados, nomeadamente crimes de sangue e homicídios. Sobretudo nas áreas mais remotas do município, onde a presença e a legitimidade do Estado é escassa, ou mesmo nula.

- Uma terceira conclusão aponta para uma área de descontinuidade significativa em relação ao período colonial. Como se demonstrou, no período colonial os "indígenas" não estavam abrangidos pelo quadro jurídico e constitucional da República portuguesa, e os seus quadros jurídicos costumeiros eram a sua "Lei e Constituição". Contudo, hoje existe uma Constituição angolana, e um quadro jurídico nacional, que se aplica universalmente a todos os cidadãos. A existência de um pluralismo jurídico não pode, nem deve, sobrepor este quadro nacional, nem muito menos deslegitimá-lo.

Ora, algumas das práticas jurídicas ilustradas pelo exemplo do Bailundo, demonstram que, em certos casos, existem profundas ilegalidades e mesmo inconstitucionalidades, nomeadamente numa área da vida social fundamental para as populações, como o caso da feitiçaria ou, melhor dito, do oculto, que o Estado não controla, e que o direito nacional não sabe como resolver. $\mathrm{E}$ que nem as populações lhe conferem legitimidade para tal. O Estado (aqui no sentido dos seus representantes locais) está profundamente consciente destas práticas e destas inconstitucionalidades, e já tem mesmo actuado para as corrigir, e punir, como também aqui se sublinhou, mas nem sempre isso acontece, quer por incapacidade, quer até mesmo por desconhecimento destes casos. Deixando no ar a ideia de que a sua intervenção só se efectua quando estes casos atingem uma certa notoriedade pública.

- Finalmente, uma quarta e última conclusão, e que constitui igualmente uma fortíssima descontinuidade com o passado colonial. Em face da modernização e mudança social provocadas pela crescente urbanização dos espaços rurais, pela extensão do sistema educativo, pelas migrações 
de populações durante a guerra, etc., denota-se hoje que as autoridades tradicionais, e os "costumes tradicionais", começam a perder legitimidade e sentido para partes significativas da população rural, nomeadamente para os jovens das sedes de município, mais "próximos" socialmente destes factores de mudança social e de modernidade.

Pelo exemplo do Bailundo, conclui-se que estes jovens optam hoje por uma atitude pragmática, jogando entre dois universos diferentes, neste caso entre dois universos jurídicos (ou dois sistemas de ordenações jurídicas), o Estatal e o tradicional-M'Balundu, que em muitas áreas se opõem. Estes novos actores sociais, já não se encontram "encapsulados" pelo sistema tradicional, nem pelos seus significados culturais, mas usam-no na actualidade, ou por outra "viajam" entre os dois, à medida dos seus interesses próprios.

\section{Referências bibliográficas citadas}

Bayart, J-F. 1989. L'État en Afrique. La politique du ventre. Paris, Editions Fayard. Coimbra, A. M. 2008. O direito oficial e o direito costumeiro no estado colonial. $O$ caso de Moçambique. Dissertação de Mestrado em Estudos Africanos. Lisboa, ISCTE.

Dialamikua, A. S. (coord). 1996. Relatório de inquérito sobre o enquadramento institucional das autoridades tradicionais na administração local. Luanda, Ministério da Administração do Território.

\section{Entrevistas:}

EBai2004-1: Administradora do município do Bailundo, Dona Beatriz. Sede da Administração Municipal. Vila-sede do Bailundo. Entrevista não-gravada. 19/08/2004.

EBai2004-2: Rei Ekuikui IV, soma inene do Bailundo, sr Augusto Katchiopololo, de 90 anos de idade. Vila-sede do Bailundo, montanha sagrada de Halavala. Entrevista gravada. 20/08/2004.

EBai2004-3:Vice-administrador da comuna de Luvemba, sr. Craveiro Lopes. Sede da comuna de Luvemba, aldeia de São Miguel. Entrevista não-gravada. 31/08/2004.

EBai2004-4: Ossoma Jino Kaiangula, de 48 anos, ombala Chijamba. Comuna de Luvemba, na ombala. Entrevista gravada. 31/08/2004.

EBai2004-5:Administrador da comuna de Lunge, sr. Joaquim Jamba. Sede da comuna de Lunge. Entrevista não-gravada. 01/09/2004. 
EBai2004-6: Ossoma Adolfo Chitoma, ombala de Lunge. Sede da comuna de Lunge. Assistiram também os Srs. Gregório Cunhajo, Simão Bemba e Raul Nambelo, membros do elengo. Entrevista gravada. 01/09/2004.

EBai2004-7: Ossoma Manuel Savilinga da ombala de Janjo, 79 anos de idade. Comuna de Luvemba, aldeia de Janjo. Entevista gravada. Devido às "condições" psicológicas do Sr. Manuel Savilinga, a entrevista acabou por ser conduzida com um elemento do elengo. 03/09/2004.

EBai2004-8: Rei Ekuikui IV, soma inene do Bailundo, sr Augusto Katchiopololo, de 90 anos de idade. 2. ${ }^{\text {a }}$ entrevista. Vila-sede do Bailundo. Entrevista gravada. 06/09/2004.

EBai2004-9: Entrevista colectiva com quimbandeiros. Isaka Fumela, José Ferreira, Martinho Kangila, Horácio Manuel, António Chamada, Paulino Domingo, Fernando Adonho Mbonga, Lourenço Adão, Débora Ngueve (santa), Craciana Samba, Mário Fernando. Vila-sede do Bailundo. Entrevista gravada. 06/09/2004.

EBai2004-10: 1 . $^{\circ}$ Secretário Municipal do MPLA, Sr. Manuel André. Presentes o 2. ${ }^{\circ}$ Secretário, sr. Emiliano Rafael Chingende; Secretário das Finanças, Sr. Agostinho Saquala; Coordenadora da Comissão de Disciplina e Auditoria, $\mathrm{Sr}^{\mathrm{a}}$ Bernardete Schogovia. Sede do MPLA, vila-sede Bailundo. Entrevista não-gravada. 07/09/2004.

EBai2004-11: $1{ }^{\circ}$ Secretário Municipal da UNITA, sr. Nataniel Ecolelo. Sede da UNITA, vila-sede do Bailundo. Entrevista não-gravada. 07/09/2004.

EBai2004-12: Reverendo Afonso Júnior Dingu, pastor da IECA (Igreja Congregacional de Angola), director do Sínodo do Bailundo. Sede do Sínodo, vila-sede do Bailundo. Entrevista gravada. 09/09/2004.

EBai2007-01:Celestino Ambrósio, Chefe de Gabinete do vice-Administrador Municipal. Vila-sede do Bailundo. Entrevista não gravada. 06/08/2007.

EBai2007-02: Entrevista colectiva com membros da AAAT, Sr. Andulosse Samemba, presidente municipal da Associação Angolana das Autoridades Tradicionais, e sékulu da ombala Canjabão; Joaquim Calado, vice-presidente, sékulu da ombala Bonga; Afonso Cajinje, secretário, sékulu da ombala Kandimba. Vila-sede do Bailundo. Entrevista gravada. 07/08/2007.

EBai2007-03: Entrevista colectiva com mulheres apoiantes da UNITA. Vila-sede do Bailundo. Entrevista não-gravada. 09/08/2007.

EBai2007-04: Entrevista colectiva com grupo de jovens do $2{ }^{\circ} \mathrm{Ciclo}$, com idades entre os 17 e os 19 anos. Vila-sede do Bailundo. Entrevista não-gravada. $15 / 08 / 2007$. 
EBai2007-05: Gabriel Caála, Procurador do município do Bailundo. Vila-sede do Bailundo. Entrevista não gravada. 24/08/2007.

EBai2007-06: Abel Ngunje, de 71 anos de idade, ossoma da ombala Chilumbe. Vila-sede do Bailundo. Entrevista gravada. 25/08/2007.

EBai2007-07: Paulo José Cuianga Romeu, administrador da comuna de Bimbe. Aldeia de Bimbe. Entrevista não-gravada. 01/09/2007.

EBai2007-08: Mário Jorge Calesse, de 67 anos de idade, ossoma da ombala de Chilala. Aldeia de Bimbe. Entrevista gravada. 01/09/2007.

EBai2007-09: Cândido Uquélonga, de 81 anos de idade. Vila-sede do Bailundo. Entrevista gravada. 06/09/2007.

Estatuto político, civil e criminal dos indígenas da Guiné, Angola e Moçambique, 1939 [1929], aprovado pelo decreto Lei n. ${ }^{\circ}$ 16473, de 6 de Fevereiro de 1929. Luanda, Imprensa Nacional.

Feijó, C. 2000. O poder local em Angola. [online]. Luanda, Ordem dos Advogados de Angola. [Consultado em 20-01-2004]. Disponível em: http://www.oaang. org/poderlo.htm.

Fernandes, T. 2009. O poder local em Moçambique. Descentralização, pluralismo jurídico e legitimação. Porto, Edições Afrontamento.

Florêncio, F. 2003. Autoridades tradicionais vaNdau, estado e política local em Moçambique. Dissertação de Doutoramento, Lisboa, ISCTE.

Florêncio, F. 2005. A procura dos mambo vaNdau. Estado e autoridades tradicionais em Moçambique. Lisboa, ICS.

Florêncio, F. 2008. Autoridades tradicionais vaNdau de Moçambique: o regresso do indirect rule ou uma espécie de neo-indirect rule? Análise Social, 43(2): 369-391.

Florêncio, F. 2009. Un reino, dos reyes. Diferentes legitimidades en Bailundo (Angola). Revista CIDOB d'Afers Internacionals, 87: 167-189.

Guedes, A. M.; Lopes, M. J. (eds.) 2007. State and traditional law in Angola and Mozambique. Coimbra, Almedina.

Guedes, A. M. 2007. The state and traditional authorities in Angola: mapping issues. In: Guedes, A.M.; Lopes, M. J. (eds.) State and traditional law in Angola and Mozambique. Coimbra, Almedina.

Grupo técnico para as questões jurídico-legais, 2001. Plano Estratégico da Desconcentração e Descentralização Administrativas: o Poder Local Autárquico e o Poder Tradicional em Angola, Conselho de Ministros da República de Angola. Lombard, J. 1967. Autorités traditionelles et pouvoirs européens en Afrique Noire. Paris, Librairie Armand Colin. 
MAT (Ministério da Administração do Território). 2002. Relatório síntese sobre o 1. ${ }^{\circ}$ Encontro Nacional sobre a Autoridade Tradicional em Angola. Luanda, Ministério da Administração do Território.

MAT (Ministério da Administração do Território). 2003. Estudo Sobre a MacroEstrutura da Administração Local. (Contribuição para a Desconcentração e Descentralização). Luanda, Ministério da Administração do Território.

Migdal, J. S. 1988. Strong societies and weak states. State-society relations and state capabilities in the third world. Princeton, Princeton University Press.

Orre, A. 2007. Integration of traditional authorities in local governance in Mozambique and Angola - the context of decentralization and democratization. In: Guedes, A. M.; Lopes, M. J. (eds.) State and Traditional Law in Angola and Mozambique. Coimbra, Almedina: 139-199.

Reforma administrativa ultramarina. 1933. Decreto Lei n. ${ }^{o}$ 23:229 de 15 de Novembro. Lourenço Marques, Imprensa Nacional de Moçambique.

Soremekun, F. 1965. A History of the American Board Mission in Angola, 18801940. PhD Thesis. Illinois, Northwestern University. [microfilmado].

Tiny, N. N. 2007. The politics of accommodation: legal and constitutional issues. In: Guedes, A. M.; Lopes, M. J. (eds.). State and traditional law in Angola and Mozambique. Coimbra, Almedina: 67-84.

Trotha, T von. 1996. From administrative to civil chieftaincy. Some problems and prospects of African chieftaincy. Journal of Legal Pluralism and Unofficial Law, 37/38: 79-107.

\section{Referências bibliográficas de pesquisa}

Arjago, A. G. 1999. Epàtá L’Usòmá. Apontamentos étno-Históricos Ovimbundu. Lobito, Edição do autor.

Arjago, A. G. 2002. Os Sobas. Apontamentos étno-históricos sobre os Ovimbundu de Benguela. Benguela, Edição do autor.

Bender, G. J. 2004. Angola sob o domínio português. Mito e realidade. Luanda, Editorial Nzila.

Birmingham, D. 2002. “Angola”. In: Chabal, P. (ed.) A history of postcolonial lusophone Africa. London, Hurst \& Company: 137-185.

Buur, L.; Keyd, H. M. (eds). 2007. State recognition and democratization in SuSaharan Africa. A new dawn for traditional authorities? New York, Palgrave Macmillan. 
Cabral, A. 1925. Projecto de Regulamento de Justiça Penal Indígena.

Cabral, A. 1925. Projecto de Código de Milandos.

Childs, G. M. 1964. The Kingdom of Wambu (Huambo): A tentative chronology. The Journal of African History, 5(3): 367-379.

Childs, G. M. 1970. The chronology of the Ovimbundu Kingdoms. The Journal of African History, 11(2): 241-248.

Clarence-Smith, G. 1989. Le problème ethnique en Angola. In: Chrétien, J-P; Prunier, G. (eds.) Les ethnies ont une histoire. Paris, Karthala: 404-415.

Diamang, Companhia de Diamantes de Angola, Direcção Geral do Dundo, Museu do Dundo, Relatório Mensal n. ${ }^{\circ}$ 5, 10/07/ 1948.

Dias, J. 1989. Relações económicas e de poder no interior de Luanda ca. 18501875. In: Actas da I Reunião Internacional de História de África. Relação Europa-África no 3. ${ }^{\circ}$ quartel do Séc. XIX. Lisboa, IICT/ Centro de Estudos de História e Cartografia Antiga.

Dias, J. 1985. Changing patterns of power in the Luanda hinterland. The impact of trade and colonisation on the Mbundu ca. 1845-1920. Paideuma, 32: 285-318.

Dias, J. 1976. Black chiefs, white traders and colonial policy near the Kwanza: Kabuku Kambilo and the Portuguese, 1873-1896. Journal of African History, 17(2): 245-265.

Edwards, A. 1962. The Ovimbundu under two sovereignties. London, Oxford University Press for International African Institute.

Fonga, 2001. FONGA na promoção do poder tradicional. [Online]. [Consultado em 10-11-2003]. Disponível em: http://www.novavisao.org/novidades/tradicional 1.htm.

Hambly, W. D. 1934. Occupational ritual, belief, and custom among the Ovimbundu. American Anthropologist, 36(2): 157-167.

Hastings, D. A. 1933. The official of a tribe. Chapter IV In: Ovimbundu Customs and Practices as Centered Around the Principles of Kingship and Psychic Power. PhD Thesis. Kennedy School of Missions, Hartford Seminary Foundation.

Heywood, L. 1998. Towards an understanding of modern political ideology in Africa: the case of the Ovimbundu of Angola. The Journal of Modern African Studies, 36(1): 139-167.

Heywood, L. 2000. Contested power in Angola: 1840s to the present. Rochester, University of Rochester Press.

Miller, J. C. 1976. Kings and Kinsmen: early Mbundu states in Angola. Oxford, Clarendon Press. 
Moreira, A. 1955. Administração da justiça aos indígenas. Lisboa, Agência Geral do Ultramar.

Neto, M. C. 1994. Comércio, religião e política no sertão de Benguela: O Bailundo de Ekwikwi II (1876-1893). Fontes \& Estudos, 1: 101-118.

Neto, M. C. 1995. Hóspedes incómodos: Portugueses e Americanos no Bailundo no último quartel do século XX. In: Actas do Seminário Encontro de Povos e Culturas em Angola - Luanda, $3^{a} 6$ de Abril de 1995. Lisboa, CNCDP.

Neto, M. C. 1997. Entre a tradição e a modernidade: os Ovimbundu do planalto central à luz da história". Ngola, Revista de Estudos Sociais, 1: 193-215.

Neto, M. C. 2000. Grandes projectos e tristes realidades. In: A África e a Instalação do Sistema Colonial (c. 1885 - c.1930) - Actas da III Reunião Internacional de História de África. Lisboa, IICT-CEHCA: 513-525.

Neto, M. C. 2002a, Do passado para o futuro que papel para as autoridades tradicionais? In: Fórum Constitucional - Huambo, NDI, FES, Universidade Católica de Angola e ADRA-Huambo, 16-18 Março.Huambo.

Neto, M. C. 2002b. Respeitar o passado - e não regressar ao passado. In: MAT, I Encontro Nacional sobre a Autoridade Tradicional, 20-22 Março. Luanda.

Nieuwaal, E. A. Rouveroy van, 1999. Chieftaincy in Africa: three facets of a hybrid role. In: Rouveroy van Nieuwaal, E.A.; Rijk van Dijk (eds.) African chieftaincy in a new socio-political landscape. Leiden, African Studies Centre.

Nieuwaal, E. A. Rouveroy van, 1996. States and chiefs. Are chiefs mere puppets? Journal of Legal Pluralism and Unofficial Law, 37/38: 279-305.

Pacheco, F. 2001. Rural communities in Huambo. In: Robson, P. (ed.) Communities and Reconstruction in Angola: the prospects for reconstruction in Angola from community perspective. Guelph, Development Workshop - Occasional paper n. ${ }^{\circ} 1$.

Paiva Couceiro, H. 1892. Relatório da viagem entre Bailundo e as terras do Mucusso. Lisboa, Imprensa Nacional.

Pélissier, R. 1986. História das campanhas de Angola. Resistências e revoltas 1845-1941. vol. I e II. Lisboa, Editorial Estampa.

Perrot, C-H.; Fauvelle-Aymar, F-X. (eds.) 2003. Le retour des Rois. Les autorités traditionnelles et l'État en Afrique contemporaine. Paris, Karthala.

Possinger, H. 1973. Interrelations between economic and social change in rural Africa: the case of the Ovimbundu of Angola. In: Heimer, F-W (ed.) Social change in Angola. Munchen, Weltforum Verlag: 32-52. 
Possinger, H. 1986. A transformação da sociedade Umbundu desde o colapso do comércio das caravanas. Revista Internacional de Estudos Africanos, 4-5: 75-158.

Redinha, J. 1974. Etnias e culturas de Angola. Luanda, Instituto de Investigação Científica de Angola.

Robson, P. (ed). 2001. Communities and reconstruction in Angola: the prospects for reconstruction in Angola from community perspective. Guelph, Development Workshop - Occasional paper $n .^{\circ} 1$.

Viegas, F.; Katyavala, J. M. 2004. Relatório final - estudo sobre o poder residual das autoridades tradicionais: o caso da província do Huambo. Huambo, MONUA \& Development Workshop.

Vieira da Silva, J.; Morais, J. A. 1973. Ecological conditions of social change in the central highlands of Angola. In: Heimer, F-W. (ed.) Social change in Angola. Munchen, Weltforum Verlag: 93-109.

Wheeler, D. C.; Christensen, D. 1973. The rise with one mind: the Bailundo war of 1902. In: Heimer, F-W. (ed.) Social change in Angola. Munchen, Weltforum Verlag: 53-92.

Artigo recebido a 26 de Fevereiro de 2010 e aceite a 18 de Junho de 2010 . 